NBER WORKING PAPER SERIES

FIRMS' CHOICE OF METHOD OF PAY

Charles Brown

Working Paper No. 3065

NATIONAL BUREAU OF ECONOMIC RESEARCH

1050 Massachusetts Avenue

Cambridge, MA 02138

August 1989

This research was supported by the National Science Foundation (Grant 8708370). The author is grateful to Nancy Lemrow. Thomas Hungerford, and Marsha

Silverberg for research assistance. I have benefited from helpful suggestions by seminar participants at the NBER and these universities: Chicago, Cornell, Georgetown, Illinois, Kentucky, Michigan, and Toronto. Copies of the data and computer programs used to generate the results presented in this paper are available from the author. This paper is part of NBER's research program in Labor Studies. Any opinions expressed are those of the author not those of the National Bureau of Economic Research. 


\section{FIRMS' CHOICE OF METHOD OF PAY}

\section{ABSTRACT}

Three types of pay-setting methods are piece rates (pay mechanically linked to output), merit pay (pay based on less formal judgments by one's supervisor), and standard rates (pay based on one's job classification and perhaps seniority, but not directly on performance). Firms' choice among methods depends on balancing the gains from more precise links between performance and pay against the costs of either precise or judgmental measures of output. Using data from the BLS Industry Wage Study program, hypotheses suggested by this observation are tested and for the most part confirmed. 
The importance of differences in methods of pay is not a new topic, ${ }^{1}$ but it is one which has received increasing attention from academic researchers and compensation specialists. Its claim to academic attention rests largely on the hypothesized relationship between methods of wage payment and the cost of monitoring workers in different contexts - a theme which, in turn, lies at the heart of recent theoretical insights about the structure of wages. Improvements in technology, particularly the growing use of computers in the office and the factory, and even in long-haul trucking, are reducing dramatically the cost of monitoring workers in some industries. ${ }^{2}$ Compensation specialists have noted a decline in the link between pay and performance, and many predict the crisis of competitiveness facing U.S. firms will force a re-strengthening of this link for both managerial and non-managerial employees (McLaughlin, 1986; Morse, 1986). ${ }^{3}$ Meanwhile, on the other side of the Pacific, "there is starting to be a shift away from pay by seniority and towards pay determined by merit" in Japan as well (Maidment, 1987, p. S-18). But problems in implementing pay for performance contracts run into monitoring problems which are stressed in the academic literature. To pick an example of general interest, consider the contract of New York Jets quarterback Ken O'Brien, under which part of O'Brien's pay is keyed to his NFL quarterbacks' rating, which penalizes incomplete passes but not sacks. Said former Jets quarterback Joe Namath, "I'm amazed at [O'Brien's] accuracy, but I see him hold the ball more than he should. I always thought it was better to have second and 10 than second and 18. I don't like incentive contracts that pertain to numbers."

We have a relatively straightforward theory of the determinants of method of pay, which in essence asserts that different methods of pay offer different 
approximations to an idealized pay-for-performance incentive for workers, but carry different costs. In general, the link between pay and performance will be stronger where performance is more accurately observed (e.g., piece rates), but such accuracy is likely to be expensive. Hence, across firms or jobs within a firm, variations in costs and benefits of accurate monitoring are hypothesized to explain differences in method of pay.

This approach receives considerable support in the prescriptive treatments in personnel texts (though it appears the topic commands less attention over time in such texts) and in a quite limited set of empirical analyses. Perhaps little empirical work in the spirit of the new personnel economics has been devoted to these issues because data in household surveys and most establishment surveys are not very helpful. The purpose of this paper is to provide such an analysis.

\section{Existing Theoretical Models}

A recent paper by Lazear (1986), which presents several models of the choice of method of pay, ${ }^{4}$ provides a convenient point of departure. Existing models generally assume the firm has two choices: paying piece rates, in which case earnings increase dollar for dollar with an objective measure of value of output, or paying time rates (or salaries), in which case earnings do not depend on what is produced. To simplify, I will assume the work-week is fixed, which means that earnings per period are fixed under the latter system.

In the simplest model of this sort, each worker's productiveness is fixed (effort is not an issue), and the methods of pay sort workers among firms. Workers know their own productivity, but firms do not, unless they pay a monitoring $\cos t \theta$. The firm can either pay $\theta$ to measure a worker's productivity $q$ directly, in which case it pays the worker q- $\theta$, or not pay the cost of the piece-rate 
monitoring system and pay salary S. The piece rate structure obviously satisfies the zero-profit requirement. Firms using salaries must in equilibrium choose $\mathrm{S}$ so they, too, earn zero profits. Since workers know their own q's, they choose the type of firm in which their earnings are highest: workers with $q>S+\theta$ choose piece-rate firms and those with $\mathrm{q}<\mathrm{S}+\theta$ choose the firms paying salaries. (See Figure 1.) If $q$ has density and c.d.f. $f(q)$ and $F(q)$ respectively, the zero-profit condition is

$$
S=\frac{1}{F(S+\theta)} \int_{0}^{S+\theta_{q f}(q) d q}
$$

Lazear shows that an $S>0$ satisfying this condition exists so long as $\theta>0$. Thus, the salary firms save on monitoring costs and pay lower wages, but this is just balanced off by their having less productive workers.

The most obvious prediction of this simple model is that, within an occupation, those paid piece rates will have higher earnings than those who are paid time rates. Available evidence supports this prediction (King, 1975; Pencavel, 1977; Seiler, 1984).

A second prediction is that, as the costs of directly monitoring output increase, fewer workers will work in piece-rate firms. This is clear from Figure 1. An increase in $\theta$ shifts down the $w(q)$ function for piece rate firms. The initial effect of this is to increase the number of workers receiving time rates, and to allow time-rate firms to earn positive profits (since the additional workers have $q_{0}{ }^{\prime}>q_{>}>q_{0}$ but they are paid $S$, the average of $q$ from zero to $\left.q_{0}\right)$. This in turn raises the wages offered by time-rate firms, further increasing their share of the workforce. 
The above model emphasized sorting of workers with different abilities. An alternative is to emphasize worker effort. The key distinction between ability and effort is that the latter is controlled by the worker, and can be manipulated by the firm by offering appropriate incentives. Because workers are assumed to find greater effort distasteful, however, we must assume that there is some minimum level of effort $\bar{E}$ which firms can observe cheaply; ${ }^{5}$ workers who do not work at this level of effort are discharged by time-rate firms.

A worker who puts forth effort $E$ produces $E$ units of output, but at psychic cost $C(E)$. The piece rate firm pays a wage equal to $E-\theta$ and, if the worker works under a piece-rate system, his/her utility is E- $\theta-C(E)$. Utility is maximized at $\mathrm{E}^{*}$, where $C^{\prime}\left(E^{*}\right)=1$, and utility is $U^{*}$. Alternatively, if the individual works in a time-rate firm, an effort level $\overline{\mathrm{E}}$ is required, and a salary $\overline{\mathrm{S}}$ is paid. The worker achieves utility $\bar{U}=\bar{S}-C(\bar{E})=\bar{E}-C(\bar{E})$, since $\bar{S}$ must equal $\bar{E}$ to satisfy the zero-profit condition. The worker compares $U^{*}$ to $\bar{U}$ and chooses the firm offering the greater utility.

To strengthen the comparison with the earlier model, assume that workers differ in their cost-of-effort functions. Let $C(E)=E^{2} / N$, where $N$ represents the energy (or ability) of the worker: workers with higher $N$ produce a given (increment to) $E$ at lower (marginal) cost. Then $\bar{U}=\bar{E}-\bar{E}^{2} / N$ is the utility offered by time-rate firms. Under piece rates, the worker chooses $E^{*}=N / 2$ and attains utility level $U^{*}=(N / 4)-\theta$. Workers are sorted across firms by their value of $N$, as shown in Figure $2 .^{6}$

As drawn in Figure 2, the implications are similar to those of the previous model: piece-rate workers earn higher wages, and an increase in the cost of 
running a piece-rate system increases the fraction of workers (range of $\mathrm{N}$ values) which prefers time rates.

\section{Three-Choice Models}

The assumption that pay of time-rated workers is unrelated to productivity is overly restrictive-at least for some time-rated blue-collar workers and a clear majority of clerical and technical workers (Cox, 1971; BNA, 1981; Personnick, 1984). Within the general category of time-rated workers, some receive wages which depend on job category and perhaps seniority but not performance, while others' wages are set individually based on supervisors' perceptions of their productivity. A generalization which allows the firm to choose among three wagesetting methods-one in which wages depend only marginally on performance ("standard rates"), one in which they depend on supervisors' evaluations ("merit pay"), ${ }^{7}$ and a piece rate system -is developed in this section. The empirical motivation for this way of defining the boundaries between methods will be clearer when the data are described later in the paper.

Suppose there are three intensities of monitoring, and for any monitoring strategy $j$ the expected wage offered a worker of quality $q$ is a linear function of $q$ :

$$
w_{j}=a_{j}+b_{j} q .
$$

The statistical discrimination literature (Aigner and Cain, 1977; Lundberg and Startz, 1983; Garen, 1985) shows that the relationship between expected wage and worker quality will be steeper (i.e., $b_{j}$ will be larger) the more accurate the available productivity indicator. If all three monitoring intensities are used, and $b_{1}<b_{2}<b_{3}$, it must be that $a_{1}>a_{2}>a_{3}$. Since the cost of monitoring workers is presumably lower if the monitoring strategy is less accurate, and the $\operatorname{cost} \theta_{\mathrm{j}}$ is 
subtracted from a worker's vmp in setting the wage, differences in $\theta$ contribute to this ranking of the a's.

As in Lazear's model, assume that piece rates correspond to a precise but expensive measuring of physical output. Merit pay offers a less expensive but less accurate alternative. ${ }^{8}$ Part of the weaker link between pay and performance under merit pay comes from errors in supervisors' ratings of performance; the peculiar feature of most merit-pay systems that increments feed into the base wage contributes as well (Schwab and Olsen, 1989). Firms using standard rates presumably spend little on measuring performance, since they do not use it in wage-setting. ${ }^{9}$

Let $\mathrm{S}, \mathrm{M}$, and $\mathrm{P}$ denote standard rates, merit pay, and piece rates, respectively. Figure 3 shows a three-method generalization of Figure 1 . While $b_{S}$ may be greater than zero and $b_{\mathrm{P}}$ may be less than one, the essential difference here is that merit pay is added as an intermediate method of pay.

If the costs using a particular monitoring intensity or the benefits of better performance indicators change, the use of the three monitoring intensities and their associated methods of pay will also change. An increase in $\theta_{j}$ leads $w_{j}(q)$ to shift downward, and the number of workers who opt for that method falls.

The benefits of better performance indicators are presumably larger where differences in worker productiveness are larger. In the limiting case where all workers are equally productive, expenditures to assess their performance would not be profitable.

To be more precise, suppose wage offers are

$$
w_{j}=a_{j}+b_{j} v q
$$


where $v$ depends on the sensitivity of output to worker quality. Let $v$ initially equal one, as in Figure 3. Now let $v$ increase. The boundary between standard rate and merit pay workers, $q_{1}$, is defined by

$$
q_{1}=\frac{{ }^{a} S^{-a} M}{\left(b_{M}-b_{S}\right)^{v}}
$$

An increase in $v$ thus reduces $q_{1}$ (and $q_{2}$ ), reducing the use of standard rates and increasing the use of piece rates. ${ }^{10}$

How does the three-alternative model work when workers vary their effort in response to wage incentives? A worker who exerts effort $E$ produces $E$ worth of output and earns an expected wage of $a_{j}+b_{j} E$ if he/she works under method of pay j. A worker with energy level $N$ has utility $U_{j}=a_{j}+b_{j} E-E^{2} / N$. To maximize utility, the worker chooses effort level $E_{j}^{*}=b_{j} N / 2$, earns $w_{j}^{*}=a_{j}+b_{j}^{2} N / 2$ and attains utility level $U_{j}^{*}=a_{j}+b_{j}^{2} N / 4$. If we now plot $U_{j}^{*}(N)$, we have a diagram like Figure 3 , except that the axes are $U^{*}$ and $N$ rather than $w_{j}$ and $q$. Recognizing that the worker chooses the method of pay that offers the highest $U_{j}^{*}$, we again have the workers sorting according to $N$, and the merit-pay workers receiving wages between the low-wage standard-rate workers and the high-wage piece-rate workers.

Thus far, I have taken the supply of labor to the occupation or industry in question as given. While it is clear that this is a strong assumption, it is not clear how best to relax it. One possibility is to assume that workers face an alternative wage $\bar{w}$, independent of $q$. This is reasonable if workers do not know their abilities, ${ }^{11}$ but when workers do know their abilities it is equivalent to assuming that ability in the occupation in question is uncorrelated with ability in alternatives. 
A less restrictive option is to assume that there is an alternative wage function $w^{a}(q)$ which must be met if workers of quality $q$ are to be attracted. While the details depend on the shape and position of the $w^{a}$ ( $q$ ) one chooses, the basic impact of including $\mathrm{w}^{\mathrm{a}}$ is to eliminate part of the $q$ distribution from Figure 3. For example, in Figure 4 workers with $\mathrm{q}_{0}<\mathrm{q}<\mathrm{q}_{1}$ still work for standard rate firms, those with $\mathrm{q}_{1}<\mathrm{q}<\mathrm{q}_{4}$ work for merit-pay firms, those with $\mathrm{q}_{4}<\mathrm{q}<\mathrm{q}_{5}$ accept alternative employment, and only those with $\mathrm{q}>\mathrm{q}_{5}$ work for piece-rate firms. It remains true that a small increase in $\theta_{\mathrm{P}}$ (shifting $\mathrm{w}_{\mathrm{P}}(\mathrm{q})$ downward) reduces the incidence of piece rates. The difference is that here a small increase in $\theta_{\mathrm{P}}$ has no effect on the number of merit-pay or standard-rate workers, and their share of employment in this market rises when the workers with $q$ slightly above $q_{5}$ leave for alternative employment.

\section{Measurable Determinants of Method of Pay}

The extension of the standard model leads to the prediction that the prevalence of each of the three methods of pay should be inversely related to the cost of using it, and that piece rates should be more common and standard rates less common where the differences in productivity among workers are greatest. Factors related to these determinants (and how they can be measured in the data described in Section II) are summarized in Table 1. These factors include those mentioned in the method-of-pay literature and in personnel texts.

Perhaps the most commonly cited indicator of monitoring costs in the economics literature is the size of establishment or firm. The classic reference here is Stigler (1962), who argued that large employers have a significant 
disadvantage in monitoring workers. For more recent studies using this premise, see Oi (1983) and Garen (1985).

A closer look at the Stigler argument makes it clear that the greater monitoring costs correspond to an increase in $\theta_{\mathrm{M}}$-greater difficulty in monitoring through supervisors' ratings - rather than an increase in $\theta_{\mathrm{P}}$. Indeed, since piecerate systems entail fixed costs which can be spread over more workers in larger establishments (Cleland, 1955; ILO, 1984), $\theta_{\mathrm{P}}$ should be lower in such workplaces. This demonstrates the practical importance of the three-way choice of method of pay. We expect larger establishments to make greater use of piece rates, less use of merit pay, and perhaps greater use of standard rates.

The argument that larger establishments have an advantage in implementing piece rate systems has a subtler implication which has not been discussed in the literature. The more separate jobs within an establishment of given size, the greater the cost of setting up and maintaining piece rates. Greater occupational dispersion raises $\theta_{\mathrm{P}}$ and should, other things equal, be associated with less use of piece rates. It may also increase the cost of a given level of accuracy for merit pay ratings in which each worker's performance is compared to the group average, because the group average would be based on fewer observations and contain more noise.

A related theme is that establishments which have long, standardized production runs or those in which individual employees perform the same tasks repetitively are amenable to piece rates. Conversely, where (due to short production runs or just the kind of jobs involved) individual workers perform a wide range of duties and there is considerable day-to-day variation in the importance of various duties, it is difficult (i.e., costly) to devise a piece-rate 
system which correctly prices each of the tasks (Cleland, 1955; Cornell, 1936; Carlson, 1982). ${ }^{12}$

An inter-related set of job characteristics-skill level and the importance of accuracy and quality of output-have conflicting impacts on method of pay. Almost by definition, high-skill jobs are jobs where worker vmp is sensitive to differences in worker quality. Thus, high skill jobs should have greater benefit from precise monitoring, and greater use of piece rates and less use of standard rates (Beach, 1975, p. 670). However, jobs in which accuracy and quality of work are important-characteristics which are often but not necessarily associated with skill level-present a situation where $\theta_{\mathrm{P}}$ is likely to be high and hence make less use of piece rates (Cornell, 1936, p. 537; Lansburgh and Spriegel, 1940, p. 416; Pencavel, 1977 , p. 232). More precisely, since piece rate systems can penalize workers.for defective pieces, it is situations where accuracy and quality are important but not easily verified which pose an obstacle to using piece rates.

A frequently mentioned cost of a piece rate system is that rapid growth of output per worker due to technological change or increased capital intensity necessitates revisions in the piece rate structure, raising the cost of piece rates. If the piece rate is adjusted downward, morale is likely to suffer. This is particularly true if the workers believe that management used piece rates to get them to work hard and then adjusted the rate downward. In principle, adjustments to reflect the fact that new machinery has made the old piece rate too generous might be accepted, but in practice determining whether the reduction is fair is difficult. A particularly clear statement of this problem is Lansburgh and Spriegel's (1940, p. 419): ${ }^{13}$ 
Really radical changes in production method, which so change the job as to make the past rate absurd, have been frequently looked upon by workers merely as an excuse for cutting rates.... This confusion between logical piece rate re-adjustments and rate-cutting results in numerous borderline cases which it is difficult to settle amicably, because there are no real data, convincing to both sides, which may be used as a basis.

Piece rates as understood in the theoretical literature link individual performance and pay. Consequently, where team production is important, measuring individual performance is more difficult and the cost of an accurate piece-rate system will be greater. Firms will avoid piece rates "[i]f the cost of determining how much each individual employee has produced at each stage in a production process is excessive" (Beach, 1975, p. 681).

The relationship between capital intensity and method of pay is complicated by the fact that capital intensity has been used as an indicator of several forces in the literature. Lazear (1986) shows that an increase in the required value of capital per worker is like a simultaneous increase in all $\theta^{\prime} \mathrm{s}$ - the cost of capital per worker is subtracted from the output of each worker under each payment system, and the use of particular payment schemes are not affected. Others have used capital intensity as a proxy for machine-paced production (e.g., McKersie et al., 1964 and Carlson, 1982, but see Pryor, 1984, p. 41 for evidence challenging this link), which reduces the attractiveness of piece rates (Cornell, 1936, p. 537; Cox, 1971, p. 55) and increases the use of standard rates (Beach, 1975, p. 680). Alternatively, greater capital intensity may be interpreted as more machinery entrusted to the worker. Since maintenance of machinery is, like quality, something which may suffer unless special measures are undertaken in a piece 
rate system, we expect less use of piece rates where capital intensity is greater. Finally, capital intensity may have an indirect effect by changing the skill level of the work. To the extent that the occupation mix is affected, the skill measures of individual occupations would capture this effect. To the extent that the skill required within occupational titles changes, a capital intensity measure will pick up that effect as well. On balance, previous research suggests that capital intensity probably should reduce use of piece rates, but this prediction depends on hard-to-verify links between capital intensity and more basic determinants of method of pay, and in having controlled adequately for the skill level of the work involved.

Goldin (1986) has argued that the femaleness of the workforce may have an important bearing on the method of pay. Her analysis compares a piece rate system to a time rate system where better performance is rewarded through future promotion, and less careful (less expensive) monitoring is employed. She argues that the latter system can be efficient for those planning stable attachment to the firm. Piece rates would be more common for female workforces, however, because the promise of future promotion is too bland a carrot for those planning short tenure with the firm. She found that women were indeed more likely to be piecerate workers, whereas men tended to be paid piece rates in integrated establishments but time rates in segregated male workplaces. ${ }^{14}$

A three-way method of pay categorization allows us to put Goldin's hypothesis to a more precise test. Not only should women be more likely to be paid piece rates, they should be less likely to be paid standard rates, since presumably the relative importance of promotion as an incentive is greatest where few within-occupation distinctions are made. An alternative view is that women 
avoid systems where supervisors have great discretion (i.e., merit pay) and concentrate in systems with the formal protection offered by either standard rates or piece rates. Both models predict women are more likely to work under piece rates (as Goldin demonstrated); they differ in their prediction about the distribution of women across merit pay vs. standard rate systems (which Goldin's data could not distinguish).

Thus far, the discussion has implicitly focused on non-union establishments, or situations where the presence of a union makes no difference for method of pay. However, Freeman (1982, pp. 4-5) has argued that unions opt for standard-rate wage systems, both as protection against arbitrariness by low-level supervisors and because eliminating wage disparities strengthens a political sense of solidarity. While Freeman's analysis focuses on the choice between standard-rate and merit-pay systems, a more explicit consideration of piece rates would be illuminating. Piece rates provide protection against supervisory discretion ${ }^{15}$ but not solidarity-enhancing wage equality. Thus, the relationship between unionization and piece rates allows us to distinguish between these motivations. The distinction has potentially important policy implications. In an environment where heavily unionized industries need improvements in productivity to remain competitive, technological monitoring could provide incentives for better performance without sacrificing protection from arbitrary supervisory discretion.

Finally, the history of firms' response to threat of unionization suggests another union-related hypothesis. Jacoby (1984) found that non-union firms threatened with unionization often adopted more formal, standardized wage structures to fend off unionization. This suggests that merit-pay systems may be 
less common among non-union firms threatened by unionization than among nonunion firms facing less serious threats.

Following the formal models on the topic, Table 1 emphasizes differences in "objective" conditions in the workplace. An alternative, more elusive factor is differences in management philosophy (Lewis, 1960, p. 462; Carlson, 1982, p. 20): some managers believe it is essential to reward productive employees, while others worry more about the harm done by distinctions which are (perceived to be) unjustified. While there is no precise measure of managerial philosophy, we can extend an idea recently introduced by Dickens and Katz (1986) in a related context. Given that office work has no obvious technological similarity to plant work across manufacturing establishments, it would be useful to know whether there is an important relationship between methods of pay of office and plant workers in an establishment. ${ }^{16}$ If, for example, one found establishments using standard rates for office workers had no particular tendency to use standard rates for their plant workers, this would tend to support the importance of factors like those in Table 1 rather than managerial style in determining methods of pay. ${ }^{17}$ 


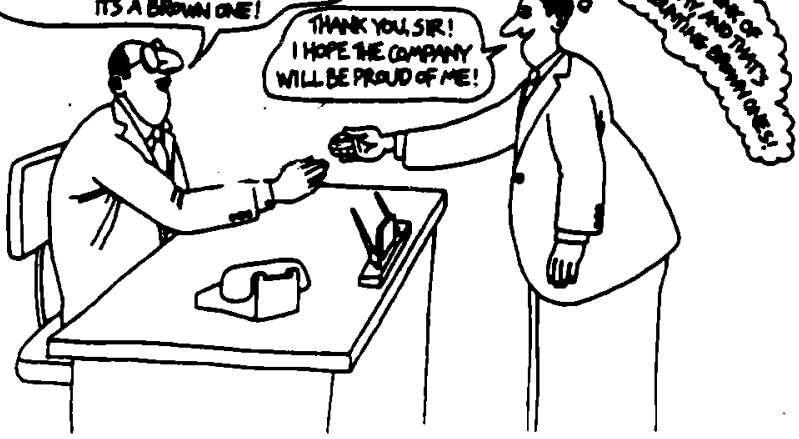

"piece-work...is encarraging to the capable, experienced worker who is eager to earn and willing to exert his best efforts." - Cornell (1955)

"The President shall...receive... compensation which shall neither be increased nor decreased during the period for which he [sic] shall have been elected...

- U.S. Constitution, Article II (Madison et al., 1787)

"There is, under this system of payment, little to urge a worker toward greater production except loyalty to his task..."

-Lansburgh and Spriegel (1940)

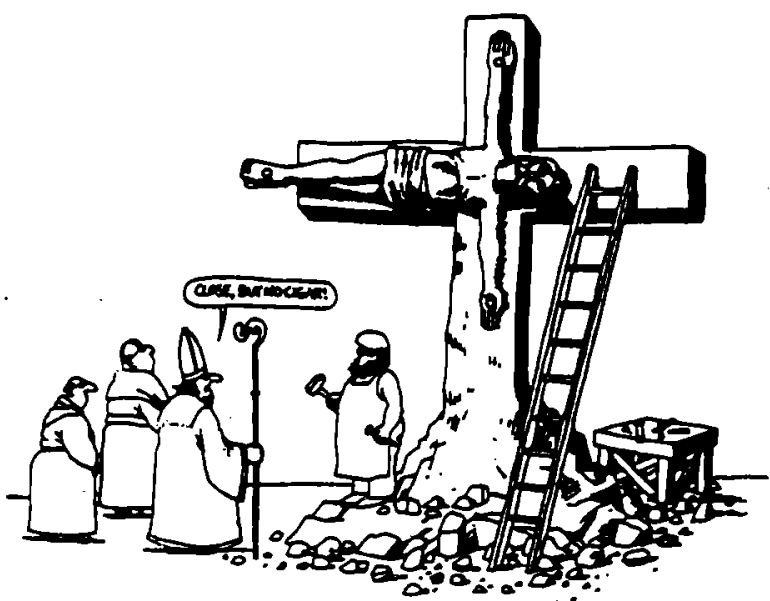

"Workers paid by the job are motivated to work quickly but they are also motivated to have minimal regard for quality [creating] a need for close supervisory attention to the quality of the work performed." -Ehrenberg and Smith (1985) 
II. Data

The Industry Wage Survey program of the Bureau of Labor Statistics provides data on methods of wage determination and other establishment characteristics. The Survey itself collects, from a sample of establishments in approximately 60 industries (four-fifths of them in manufacturing), these characteristics of the establishment:

- proportion of production (and, in a few industries, office) workers paid by various "methods of pay"

- establishment fringe benefit policies (e.g., number of holidays, vacation days at different seniority levels)

-establishment employment

- union coverage

-region

-metropolitan/non-metropolitan location

- special characteristics codes, dealing with detailed product and/or production technology, which vary from industry to industry

Ten methods of pay are distinguished, five for time rates and five for incentive pay: ${ }^{18}$

-Time Rates

- single rates-same wage for all those in a job category

-range of rates-each job category has a range of pay rates, and progression through the range is governed by:

-merit

- seniority

- combination of merit and seniority

- individual determination of wages

-Incentive Pay

-individual piece rates

-individual bonus pay (pay for exceeding production quota) 
-group piece rates

-group bonus pay

- commissions

The "single rate" and "range of rates-seniority" categories are standard-rate methods. The "range of rates-merit" and "individual determination" categories are merit-pay methods. ${ }^{19}$ "Individual piece rates", "individual bonus pay", and (negligible in these data) "commissions" correspond closely to the piece rate system in the theory. "Range of rates-combination" straddles the boundary between merit pay and standard rates. "Group piece rates" and "group bonus pay" may act like individual piece rates if groups are small, but Weiss (1987) offers strong evidence that in large groups these incentive effects may be lost. Unfortunately, we do not know group size for those paid group incentives; fortunately, these categories are fairly rare in the 10 industries studied here.

In addition, for each production worker in a subset of occupations which includes the major occupations in the industry, this information is collected:

- hourly wage ${ }^{20}$

$-\operatorname{sex}$

- whether paid by incentive or time rates

- occupation (roughly 30 occupations are distinguished for each industry) ${ }^{21}$

Table 2 shows the distribution of establishments by method of pay ${ }^{22}$ for blue collar workers in 10 industries. ${ }^{23}$ Each industry makes serious use of two or three methods, even though individual establishments typically use one or two. There is, therefore, considerable within-industry variation to explain. While union status is related to method of pay-in particular, unionized establishments 
are more likely to use standard rates (Freeman, 1982)-the variation in Table 2 is not just a reflection of differences in collective bargaining coverage. The distribution of piece-rate shares in Table 2 is similar to that in the broader set of IWS industries (Seiler, 1984, p. 365) except that industries with 60 percent or more paid piece rates are underrepresented.

The IWS data alone allow us to measure several of the determinants of method of pay in Table 1. Size of establishment is coded in eight employment classes. These were converted to a continuous variable by assigning to each category the mean establishment size (for the establishment's 4-digit industry) using data from County Business Patterns for 1977 (U.S. Department of Commerce, 1979, Table 1B). Our measure of occupational concentration is the sum (over IWS occupations) of the squared share of the occupation in the establishment's employment (based on workers in the subset of "studied" occupations). If all workers work in a single occupation, the concentration index equals one; when workers are uniformly distributed over $N$ occupations, it is $1 / N$, or close to zero.

A measure of the importance of teamwork which is admittedly crude and indirect can be constructed from the IWS data on holidays and vacations, if we assume that "teamwork" implies a need to co-ordinate the work schedules of team members (i.e., a cost to having some but not all members of the team present on any given work day). Thus, where teamwork is important, we should expect time off to take the form of coordinated leisure (holidays) rather than uncoordinated vacations. The share of holidays in total time off (holidays plus vacation days) is therefore an indirect measure of the importance of teamwork. ${ }^{24}$ Unfortunately, 
this variable was strikingly unrelated to method of pay and, given its indirect link to teamwork in the first place, was deleted from the final regressions.

The female share of employment in the studied occupations can be computed directly from the IWS worker records. Moreover, when method of pay of individual workers is considered, a dummy variable for female workers is based directly on the worker's IWS record.

The IWS also determines whether a majority of the production workers in an establishment are covered by collective bargaining. Our measure of threat of unionization is based on the predicted probability of unionization, U-hat, from a regression of a union-status dummy on the other exogenous variables. Clearly, the threat of unionization applies only to non-union firms, so our variable equals U-hat for non-union establishments and zero for those which are already unionized.

Because IWS gives the 4-digit SIC industry and employment size class of its establishments one can match them to Census of Manufacturers' data by industry-by-size cell. Specifically, the growth in output per worker is measured by the change in the logarithm of value added per worker between 1967 and $1977^{25}$ and capital intensity by $1-$ (payroll + materials)/shipments in 1977 .

The IWS also provides detailed occupation coding for workers in studied occupations-sufficiently detailed occupations to correspond closely (often identical titles) to those in the Dictionary of Occupational Titles. From the DOT file, we have matched three types of variables. First, our primary skill measures are the three indicators of General Educational Development (reasoning, mathematics, and language) and the required level of Specific Vocational Preparation. In addition, the DOT rates occupations on a 5-point scale for 11 aptitudes, ranging 
from math ability to foot-eye coordination; the maximum of these aptitude ratings is used as an additional skill indicator. ${ }^{26}$ Second, the DOT indicates whether an occupation requires a tolerance of changing duties or a tolerance for repetitive work. The difference between these variables (which takes the values $-1,0,1$ ) is used as a measure of diversity of duties. Third, the DOT indicates whether the job requires "adaptability to situations requiring the precise attainment of set limits, tolerances, or standards"-which seems to be a natural indicator of the importance of accuracy and quality. However, the precision described in this variable may well be an easily checked sort, so penalties for substandard pieces (and hence piece rates) would be feasible after all. Alternative DOT variables indicate whether the job requires aptitude for making "generalizations, evaluations or decisions" based on "sensory or judgmental criteria" or based on "measurable or verifiable criteria." The sum of these two dummy variables is an index of the extent to which the job requires the sort of work where care is important but haste is difficult to penalize. Therefore, less use of piece rates would be expected where such judgments are important.

\section{Establishment-Level Regressions}

Table 3 presents a set of equations showing the relationship between the proportions of workers paid incentive pay and standard rates (with merit pay the omitted category), using different combinations of the IWS methods of pay for these categories. Table 4 presents similar equations, but with the sample divided into union and non-union establishments.

The results for (ln-) establishment size are as predicted by models in which difficulty monitoring workers leads large employers to avoid merit pay and use either standard rates or incentive pay instead. Larger establishments are more 
likely to use incentive pay in both union and non-union settings; their greater use of standard rates is true in the aggregate ard in non-union establishments, but not in union workplaces. The related hypothesis that occupational concentration encourages piece rates and perhaps discourages standard rates is not supported by the data. The coefficients are wrong-signed though not very precisely estimated.

As noted previously, "skill" which is measured here by a wage-weighted occupation index (based on workers in studied occupations) has theoretically indeterminate effects on methods of pay. In the data, there is little consistent relationship between the skill index and method of pay.

One hypothesis which does not fare well is that rapid growth in value added per worker is a deterrent to use of piece rates. Coefficients are wrong-signed and sometimes significant. One technical explanation for this failure is that the variable is matched to IWS establishments based on industry and establishment size, and both industry dummies and establishment size are also entered in the equations. However, there is a considerable amount of variation in the industry by size cells not accounted for by the dummies and $\ln ($ establishment size): when the change in value added per worker is regressed on these variables, only 34 percent of the variation is explained. A more substantive explanation may be that large jumps in output per worker are characterized by dramatic changes in the type of machinery in use. If so, worker opposition to changes in piece rates may be muted, since the complaint that the the change was unfair would be less credible.

The relationship between capital intensity and method of pay was theoretically ambiguous, depending on what one believes capital intensity is measuring, though discouraging use of piece rates was the most common 
conjecture. The estimates suggest that more capital intensive establishments are less likely to use piece rates and more likely to use standard rates, though they are not close to significant. The "technical" problem cited above for growing output per worker may have more force here: industry dummies and In(establishment size) account for 75 percent of the variation in our measure of capital intensity. Moreover, when industry dummies are excluded (so that the cross-industry relationship is not netted out), capital intensity is significantly (negatively) related to use of incentive pay.

As Goldin's model predicts, establishments with larger proportions of female workers are more likely to use piece rates. However, the effect on use of standard rates is either zero or positive. Goldin's model (which emphasizes the importance of providing immediate incentives to female employees) seems inconsistent with the latter finding. ${ }^{27}$ It is tempting to argue simply that the assumed labor force participation pattern which drives Goldin's model is no longer strong enough to produce such differences. However, that leaves the strong association between proportion female and piece rates to be explained.

As expected from others' research, unionized establishments make significantly greater use of standard-rate pay. The effects on incentive pay are insignificant, both statistically and practically. Unions neither avoid incentive pay, as the egalitarian model of unions would suggest, nor use it more often, as the block-supervisory-discretion model would have it. Rather, we seem to see both forces at work, more or less cancelling each other out.

The final explanatory variable in the table is the threat of unionization, defined so that high values represent establishments which are non-union but which have high "predicted" values of being union, and are therefore plausibly 
regarded as threatened by unionization. I hypothesized that such establishments would be more likely to use standard-rate pay systems in an attempt to head off unionization. Table 3 shows no evidence of this happening. An admittedly afterthe-fact explanation may be that establishments which have remained non-union despite being in industries etc. which are unionized may be exactly the ones which have the most to lose from union practices like standard rates, and hence devote more resources to remaining non-union.

One further experiment is not reported in Table 3. The IWS file for paints contained methods of pay for office workers as well as production workers. Unfortunately, this is the one industry in which there are no incentive-pay workers (see Table 1). Moreover, 80 percent of the office workers had merit pay systems (and the rest had standard rates), so there was less variation than one would like in office methods of pay. When proportion of office workers paid standard rates was added to an equation similar to the equations for standardrate pay in Table 3, but for paints alone, its coefficient was positive but very imprecisely estimated.

\section{Worker-Level Regressions}

The results in Table 5 are based on a sample of workers, one having been drawn at random from each establishment's set of workers in studied occupations. ${ }^{28}$ Before turning to the establishment-level variables in Table 5 , it is worth noting the ways in which these regressions differ from those in Table 3. First, the establishment-level methods of pay referred to all non-supervisory production workers, while Table $\mathbf{5}$ is limited to individual workers in "studied" occupations. Second, about a tenth of the potential worker sample was lost due to failure to match workers' IWS occupations to any DOT occupation. Finally, the 
coefficients reported in Table 5 control for the DOT characteristics (and include a variable for the sex of the individual worker) while those in Table 3 do not. Fortunately, the results for establishment-level variables in Table 5 are not very different from those in Table 3 . The most obvious change is that the proportion female no longer increases use of incentive pay-but the individual worker's being female does. (There is still little evidence of employers' having a comparable aversion to women in standard-rate jobs.)

The news in Table 5 is in the worker-level variables. Our various skill measures show little overall relationship to method of pay. Incentive pay is positively related to a high requirement for general reasoning skills, and negatively related to a need for general language skills. The remaining coefficients are tiny and statistically fragile. Given the theoretically ambiguous relationship between skill and method of pay we started with, one shouldn't overinterpret these results.

As predicted, jobs where workers have diverse duties have less use of incentive pay (and greater use of standard rates) than workers with unchanging duties repetitively performed. Moreover, since the variable runs from -1 to +1 , the estimated effect on use of incentive pay is practically quite significant.

The variables labeled "precision" and "generalize, evaluate, decide" were intended to capture, respectively, situations where accuracy was important but relatively easily verified and situations where judgments which would be hard to evaluate numerically were important. The former should encourage, and the latter discourage use of piece rates (with perhaps opposite-signed impacts on use of standard rates). The data strongly confirm this prediction. Again, the practical significance of the coefficients is noteworthy. 


\section{Conclusions}

The goal of this paper was to determine whether utilization of different methods of paying production workers was related in predictable ways to the costs of undertaking the monitoring which the method requires. For incentive pay, these are the costs of measuring output and setting up (and updating) the relationship between pieces and pay. For merit pay, they are the costs of sufficiently careful supervisors' ratings and of convincing the workers that these ratings should be taken seriously. The costs of standard rate pay systems are presumably negligible, though one loses the benefit of correct incentives which a well-conceived piece rate (or merit pay) system can provide. An attempt was also made where possible to account for institutional factors (unionization, or the threat of same).

In some cases, such as the effect of unionization on use of incentive pay or the effect of skill level on methods of pay in general, there was no strong a priori relationship between observable measures and methods of pay. In most of the other cases, given the undeniable difficulty in measuring the factors cited in the literature as likely to be important, the results seem to be generally in line with theoretical predictions. The results for establishment size, female workforces (on incentive pay), unionization (on use of standard rates), variety of duties, and factors related to ease or difficulty of monitoring quality of work were generally as predicted. Support for the predicted effects of occupational concentration, capital intensity, growth in value added per worker, and threat of unionization was less impressive. In my view, the last three failures may be due to problems measuring variables whose effects nay not be terribly large in the first place. I hope this 
doesn't seem like the tired refrain of measurement problems as the first refuge of scoundrels: the problems here are genuine.

One other, methodological point is noteworthy. The matching of IWS and DOT occupation codes was undertaken with the knowledge that the IWS occupations were both much more detailed and much more DOT-like in concept than, say, 3-digit Census occupations-and the hope that IWS-DOT matches would amount to more than previous attempts to match DOT and Census occupations (including my own work) had managed. That hope seems to have been confirmed. It's a pity there aren't more worker level variables on the IWS for the IWS-DOT matched job characteristics to explain! 


\section{Notes}

${ }^{1}$ Julius Caesar is said to have enhanced the effectiveness of the Roman army by implementing a performance-based salary system in lieu of booty (McLaughlin, 1986, p. 8).

${ }^{2}$ The Washington Post reported a large hotel now requires each maid to punch her ID number on the room telephone when she enters and leaves each room. Similar opportunities are available for monitoring typists using word processing packages which can record the typist's work level while performing traditional word processing. For evidence of the potential of modern technology for more precise monitoring of workers, see National Research Council (1986) and Skaiken (1987).

${ }^{3}$ A survey of compensation committee members of 350 large U.S. corporations found this was "the most important objective in the next five years" (McLaughlin, 1986, p. 7).

${ }^{4}$ An alternative approach would be to emphasize the somewhat different principal-agent literature, as developed by Harris and Raviv (1979), Holmstrom (1979 and 1982) or Green and Stokey (1983). A fundamental difference between these papers and Lazear's is the assumed source of randomness. Lazear assumes that, unless the cost of an accurate piece rate system is undertaken, the firm does not know how much the worker has produced. The principal-agent papers, on the other hand, assume that firms do observe each worker's output (an exception is part of Holmstrom's 1982 paper) but this output depends on environmental factors the worker cannot control as well as on effort, so that paying piece rates introduces risk which agents find undesirable. The extra information sought by the firm is some measure of effort, so that the worker can be partially insured in 
cases where output is low due to environmental randomness rather than worker shirking. This approach is very likely the right one for thinking about corporate CEOs or salespersons, for whom output is easily measured but environmental randomness is important. Lazear's seems better suited to the blue collar workers in the IWS, for whom environmental randomness is relatively unimportant (the most important randomness, breakdown of machines or material unavailability being easily measured) but measuring output (performance) is costly.

${ }^{5}$ If there were no minimum level of effort the firm could easily verify, workers would presumably set $E=0$ and the firm could not survive. An alternative approach is to assume there is a minimal level of effort $\bar{E}>0$ below which less effort does not raise utility.

${ }^{6}$ Figure 2 is drawn on the assumption that $\bar{E}$ is low enough relative to the minimum value of $\mathrm{N}$ that all workers with low $\mathrm{N}$ work for the salary firm. As the above algebra makes clear, $U^{*}(N)$ and $\bar{U}(N)$ will cross twice. Call the two values $\mathrm{N}^{0}$ and $\mathrm{N}_{0}$. For $\mathrm{N}>\mathrm{N}_{0}$, the worker prefers the piece rate firm and exerts $\mathrm{E}>\overline{\mathrm{E}}$. For $\mathrm{N}^{0}<\mathrm{N}<\mathrm{N}_{0}$, the worker prefers time rates. If there are any workers with $\mathrm{N}<\mathrm{N}^{0}$, however, they will prefer piece rates because they permit a leisurely pace of work below $\bar{E}$. Given that $\bar{E}$ typically corresponds to a very low level of effort (just going through the motions) and that previous studies find piece rate workers earning more, this possibility seems unlikely to be important empirically.

${ }^{7}$ Merit pay may take the form of "contests" in which each worker's rating depends on his measured performance relative to everyone else's, as in Nalebuff and Stiglitz (1983).

${ }^{8}$ One might make two objections to this classification. First, one might argue that, in some cases, piece rates are less accurate than supervisor ratings as an 
indicator of productivity (e.g., where quality of output is very important). Such a situation is consistent with the framework in the text, by describing such a situation as one where the cost of a precise piece-rate system is very high. Second, one might wonder whether merit ratings are very expensive, given that supervisors have a reasonably accurate estimate of workers' productivity which comes "free" from the act of supervising. However, a merit pay system in which considerable weight is placed on the evaluations (see next paragraph) imposes not only the cost of the supervisors writing down what they already know; morale considerations seem to demand that a serious merit-pay system be formalized so that workers will accept it as fair, and co-ordinated so that otherwise identical workers with different supervisors are not treated very differently. Finally, the personnel literature suggests it is difficult-perplexingly so to an economist-for top management to enforce sizeable merit differentials on those setting salaries at lower levels. See Hamner.1983; Strauss and Sayles, 1980.

${ }^{9}$ Our focus is on the relationship between performance and pay in the short run. We can still allow those who perform better under standard-rate regimes to have a greater probability of promotion in the future, but the relationship between pay and performance would still be "less than that associated with the other forms of compensation that are more closely tied to current output" (Barron and Loewenstein, 1986, p. 604). Future compensation is neglected in the text because it is not measured in the IWS. It is worth noting that future promotions would probably depend on measured performance under any of the systems, so neglecting them may be a defensible simplification when our focus is a comparison among systems. Also, to the extent that less accurate monitoring leaves standard-rate firms less able to identify the "right" workers to promote to higher 
positions, there is presumably a productivity loss which should be counted as part of the cost of using this system.

${ }^{10} \mathrm{I}$ am assuming that these "first-round" effects are not completely undone by subsequent changes in response to positive profits.

${ }^{11}$ Lazear (1986) introduces $\bar{w}$ when workers do not know their own abilities, but reverts to the fixed-supply model when the worker knows q.

${ }^{12}$ Cleland (1955) and Oi (1983) suggest that long standardized production runs are more characteristic of large than small establishments, reinforcing the predicted effect of establishment size.

${ }^{13}$ See also Cornell, 1936, p. 711; Pencavel, 1977, p. 233; and Carlson, 1982, p. 20.

${ }^{14}$ Pencavel (1977) found only a very weak tendency for women to be piece-rate workers, in a relatively small sample of Chicago punch press operators.

${ }^{15}$ Under an imperfect piece rate system, supervisors can still assign favored employees to jobs with "loose" rates-i.e., those which are overpriced (Beach, 1975, p. 699). The union would need to restrict such flexibility in assignment. ${ }^{16}$ Of course, office workers are almost never paid piece rates. But there is variation in the importance given to individual differences in productivity, particularly the importance of seniority vs. merit in range-of-rate systems. ${ }^{17}$ Methods of pay of office workers are available for only a minority of the IWS industries.

${ }^{18}$ A more precise definition of the IWS categories is provided in each report: Formal rate structures for time-rated workers provide single rates or a range of rates for individual job categories. In the absence of a formal rate structure, pay rates are determined primarily by the qualifications of the individual worker. A 
single rate structure is one in which the same rate is paid to all experienced workers in the same job classification. (Learners, apprentices, or probationary workers may be paid according to rate schedules which start below the single rate and permit the workers to achieve the full job rate over a period of time.) An experienced worker occasionally may be paid above or below the single rate for special reasons, but such payments are exceptions. Range-of-rate plans are those in which the minimum or maximum, or both of these rates paid experienced workers in the same job are specified. Specific rates of individual workers within the range may be determined by merit, length of service, or a combination of these. Incentive workers are classified under piecework or bonus plans. Piecework is work for which a predetermined rate is paid for each unit of output. Production bonuses are based on production over a quota or for completion of a task in less than standard time.

${ }^{19}$ This usage differs slightly from that used in compensation textbooks, where merit pay means range of rate systems in which position in the range depends on merit reviews (and perhaps seniority), and thus usually would not include a less formal "individual determination" system. For a more detailed description of what is meant by merit pay in that context, see Schwab and Olson (1989). ${ }^{20}$ The hourly wage includes piece rates and production bonuses but excludes annual non-production bonuses and premium pay for overtime, holidays, and shiftwork.

${ }^{21}$ One can get a sense of the IWS detail from this sampling of the occupations identified in the wood household furniture study: router operators (distinguished by whether they do set up work or not), rip saw operators, furniture sanders (3 types), and furniture packers. 
${ }^{22}$ Establishments which used more than one method are assigned to the three methods in Table 1 in proportion to the fraction of workers paid by each method. 23 These are the same industries analyzed by Freeman (1982), with the addition of men's and boys' shirts (which Freeman deleted because he was focusing on nonpiece-rate pay).

${ }^{24}$ The IWS vacation data are presented separately at different levels of seniority. These are converted to an overall average using distributions of workers by tenure by industry from Sekscenski (1980).

${ }^{25}$ While one cannot distinguish growth due to greater capital per worker from that due to technological change, either cause of "overly" rapid growth should reduce the incidence of piece rates.

${ }^{26}$ Using the maximum rather than the mean reflects a belief that "skill" means that unusual levels of something are required; one would not down-rate the "skill" of mathematicians (or football players) because little hand-eye coordination (language aptitude) is required for the job.

${ }^{27}$ When detailed methods of pay are used as dependent variables, proportion female is associated with a significant increase in the proportion of workers paid by range of rates:seniority.

${ }^{28}$ One drawback of the worker-level data is that the method of pay characterization is less detailed -only time-rated and incentive-paid workers are distinguished. Thus, for time-rated workers in establishments which use both standard rates and merit pay, we are not certain in which category the individual belongs. However, only about ten percent of the establishments use both standard rates and merit pay for their production workers, so this is not an overwhelming problem. It was finessed in the obvious way: for time-rated workers, the "dummy" 
variable for standard-rate workers is in fact the proportion of the establishment's time-rated workers (standard rates plus merit pay) who received standard rates. 
Aigner, Dennis and Cain, Glen. "Statistical Theories of Discrimination in Labor Markets," Industrial and Labor Relations Review, Vol. 30, 1977, pp. 175187.

Barron, John and Lowenstein, Mark. "On Imperfect Evaluation and Earnings Differentials", Economic Inquiry, Vol. 24, No. 4, October 1986, pp. 595-614. Beach, Dale. Personnel: The Management of People at Work (New York: MacMillan, 3d Edition, 1975).

Bureau of National Affairs, "Wage and Salary Administration," Personnel Policies Forum No. 131, 1981.

Carlson, Norma. "Time Rates Tighten Their Grip on Manufacturing," Monthly Labor Review, Vol. 102, No. 5, May 1982, pp. 16-22.

Cleland, Sherill. The Influence of Plant Size on Industrial Relations (Princeton NJ: Industrial Relations Section, Princeton University, 1955).

Cornell, William. Organization and Management in Industry and Business (New York: Ronald Press Co., 1936).

Cox, John. "Time and Incentive Pay Practices in Urban Areas," Monthly Labor Review, Vol. 91, No. 12, December 1971, pp. 53-55.

Dickens, William and Katz, Lawrence. "Industrial and Occupational Wage Patterns and Theories of Wage Determination," NBER Working Paper 2014, 1986.

Freeman, Richard. "Union Wage Policies and Wage Dispersion within Establishments," Industrial and Labor Relations Review, Vol. 36, No. 1, October 1982, pp. 3-21. 
Garen, John. "Worker Heterogeneity, Job Screening, and Firm Size," Journal of Political Economy, Vol. 93, No. 4, August 1985, pp. 715-739.

Goldin, Claudia. "Monitoring Costs and Occupational Segregation by Sex," Journal of Labor Economics, Vol. 4, No. 1, January 1986, pp. 1-27.

Green, Jerry and Stokey, Nancy. "A Comparison of Tournaments and Contracts," Journal of Political Economy, Vol. 91, No. 3, June 1983, pp. 349-364.

Hamner, W. Clay. "How to Ruin Motivation with Pay," in Richard Steers and Lyman Porter, eds., Motivation and Work Behavior (New York: McGrawHill, 3rd edition, 1983), pp. 264-276.

Harris, Milton, and Raviv, Arthur. "Optimal Incentive Contracts with Imperfect Information," Journal of Economic Theory, Vol. 20, No. 2, April 1979, pp. 231-259.

Holmstrom, Bengt. "Moral Hazard and Observability," Bell Journal of Economics, Vol. 10, No. 1, Spring 1979, pp. 74-91.

Holmstrom, Bengt. "Moral Hazard in Teams, Bell Journal of Economics. Vol. 13, No. 2 , pp. $324-340$.

International Labour Office. Payment by Results. Geneva: International Labour Office, 1984 .

Jacoby, Sanford. "The Development of Internal Labor Markets," in Paul

Osterman, ed., Internal Labor Markets (Cambridge MA: MIT Press, 1984). King, Sandra. "Incentive Pay in Auto Repair Shops," Monthly Labor Review, Vol. 98 , No. 9, September 1975 , pp. 45-48.

Lansburgh, Richard and Spriegel, William. Industrial Management (New York: John Wiley, 3rd Edition, 1940). 
Lazear, Edward. "Salaries and Piece Rates," Journal of Business, Vol. 59, No. 3, 1986, pp. $405-431$.

Lewis, L. Earl. "Extent of Incentive Pay in Manufacturing," Monthly Labor Review, vol. 83, no. 5, May 1960, pp. 460-463.

Lundberg, Shelly and Startz, Richard. "Private Discrimination and Social Intervention in Competitive Labor Markets," American Economic Review, Vol, June 1983. 73 , No. 3.

Maidment, Paul. "No Small Change: A Survey of Japan," The Economist, December 5, 1987, pp. S1-S34.

McLaughlin, David. "Pay for Performance: A Perspective," Topics in Total Compensation, Vol. 1, No. 1, Fall 1986, pp. 7-14.

McKersie, Robert; Miller, Caroll; and Quarterman, William. "Some Indicators of Incentive Plan Prevalence," Monthly Labor Review, vol. 84, no. 3, May 1964, pp. 271-276.

Morse, Edward. "Productivity Rewards for Nonmanagement Employees," Topics in Total Compensation, Vol. 1, No. 1, Fall 1986, pp. 85-100.

Nalebuff, Barry and Stiglitz, Joseph. "Prizes and Incentives: Towards a General Theory of Compensation and Competition," Bell Journal of Economics, Vol. 14, No. 1, Spring 1983, pp. 21-43.

National Research Council, Panel on Technology and Women's Employment. Computer Chips and Paper Clips (Washingtón DC: National Academy Press, vol. I, 1986).

Oi, Walter. "Heterogeneous Firms and the Organization of Production", Economic Inquiry, Vol, 21, No. 2, April 1983, pp. 147-171. 
Pencavel, John. "Work Effort, On the Job Screening, and Alternative Methods of Remuneration," in Ronald Ehrenberg, ed., Research in Labor Economics, Vol. 1. Greenwich, CT: JAI Press, 1977, pp. 225-258.

Personick, Martin. "White-Collar Pay Determination Under Range-of-rate Systems," Monthly Labor Review, vol. 107, no. 12, pp. 25-30.

Pryor, Frederic. "Incentives in Manufacturing: The Carrot and the Stick," Monthly Labor Review, Vol. 104, No. 7, July 1984, pp. 40-43.

Schwab, Donald and Olson, Craig, "Merit Pay Practices: Implications for PayPerformance Relationships," unpublished paper, 1989.

Seiler, Eric. "Piece Rate vs. Time Rate: The Effect of Incentives on Earnings, Review of Economics and Statistics, Vol. 66, No. 3, August 1984, pp. 363376.

Sekscenski, Edward. "Job Tenure Declines as Workforce Changes," BLS Special Labor Force Report 235, 1980.

Shaiken, Harley. "When the Computer Runs the Office," New York Times, March 22,1987 , sec. 3, p. 3.

Stigler, George. "Information in the Labor Market," Journal of Political Economy, Vol. 6, No. 5, October 1962 (supplement), pp. 94-105.

Strauss, George and Sayles, Leonard. Personnel: The Human Problems of Management, (Englewood Cliffs NJ: Prentice Hall, 3rd Edition, 1980).

U.S. Department of Commerce. County Business Patterns 1977 (Washington DC: U.S. GPO, 1979).

Weiss, Andrew. "Incentives and Worker Behavior: Some Evidence," in Haig Nalbantian, ed., Incentives, Cooperation, and Risk Sharing (Rowman and Littlefield, 1987), pp. 137-150. 
Table 1

Determinants of Method of Pay

$\begin{array}{lll}\text { Variable } & \text { Impact }\end{array}$

Size of Establishment

Occupational Concentration

Diversified Duties

Skill (Variation in vmp)

Accuracy\&Quality Important but Hard to Measure

Growth in Q/L

Capital Intensity

Importance of Teamwork

Proportion Female

Union Coverage

Threat of Unionization

$$
\uparrow \mathbf{P}, \downarrow \mathbf{M}
$$

Estab. Size (IWS)

$\uparrow \mathbf{P}$

$\downarrow P$

$\downarrow S, \uparrow \mathrm{P}$

$\downarrow P$

$\downarrow P$

$\downarrow \mathrm{P} ?, \downarrow \mathrm{M}$ ?

$\Delta \ln \mathrm{VA} / \mathrm{L}(\mathrm{COM})$

VA-Payroll

$$
\text { Shipments }(C O M)
$$

$\lfloor\mathrm{P}$

$\frac{\text { Holidays }}{\text { Total Time Off }}$ (IWS)

$\downarrow S ?, \uparrow P \quad$ Female Empl. Share (IWS)

$\uparrow S, \downarrow M, ? P$

U (IWS)

$\uparrow \mathrm{S}, \downarrow \mathrm{M}, ? \mathrm{P}$

(1-U) U-hat (IWS) 
Table 2

Establishments by Method of Pay by Industry

\begin{tabular}{|c|c|c|c|c|c|}
\hline \multirow[b]{2}{*}{ Industry } & \multirow{2}{*}{$\begin{array}{c}\text { Number } \\
\text { of } \\
\text { Establishments }\end{array}$} & \multicolumn{3}{|c|}{$\%$ of Establishments Using ${ }^{\dagger}$} & \multirow{2}{*}{$\begin{array}{c}\text { \% Covered } \\
\text { by } \\
\text { Unions }\end{array}$} \\
\hline & & $\begin{array}{l}\text { Standard } \\
\text { Rates }\end{array}$ & $\begin{array}{c}\text { Merit } \\
\text { Pay }\end{array}$ & $\begin{array}{l}\text { Piece } \\
\text { Rates }\end{array}$ & \\
\hline Nonferrous Foundries & 364 & 38 & 47 & 15 & 49 \\
\hline Paints & 292 & 58 & 42 & 0 & 62 \\
\hline Textile Dyeing \& Finishing & 149 & 72 & 20 & 7 & 49 \\
\hline Industrial Chemicals & 270 & 79 & 20 & 1 & 74 \\
\hline Cotton Textiles & 342 & 66 & 9 & 26 & 16 \\
\hline Wool Textiles & 57 & 61 & 17 & 22 & 33 \\
\hline Shirts & 220 & 3 & 23 & 75 & 28 \\
\hline Plastics & 876 & 43 & 52 & 5 & 45 \\
\hline Household Furniture & 331 & 18 & 63 & 19 & 41 \\
\hline Steel & 332 & 54 & 42 & 4 & 71 \\
\hline
\end{tabular}

$\doteqdot$ Apart from rounding error, these three columns sum to $100 \%$. 
Table 3

Method of Pay Equations

(All Establishments)

\begin{tabular}{|c|c|c|c|c|c|}
\hline & \multirow[b]{2}{*}{$\begin{array}{c}\text { Mean } \\
\text { (Std. Dev.) }\end{array}$} & \multicolumn{4}{|c|}{ Dependent Variable $=$ Proportion of Workers Paid by } \\
\hline & & $\begin{array}{c}\text { all } \\
\text { incentives }\end{array}$ & $\begin{array}{l}\text { individual } \\
\text { incentive } \\
\text { or bonus }\end{array}$ & $\begin{array}{l}\text { single rates or } \\
\text { range:seniority }\end{array}$ & $\begin{array}{l}\text { single rates or } \\
\text { range:seniority or } \\
\text { range:combination }\end{array}$ \\
\hline $\ln ($ employment $)$ & $\begin{array}{c}4.84 \\
(1.15)\end{array}$ & $\begin{array}{l}.022^{*} \\
(.004)\end{array}$ & $\begin{array}{l}.019^{*} \\
(.004)\end{array}$ & $\begin{array}{l}.034^{*} \\
(.008)\end{array}$ & $\begin{array}{l}.051^{*} \\
(.008)\end{array}$ \\
\hline $\begin{array}{l}\text { occupational } \\
\text { concentration }\end{array}$ & $\begin{array}{l}.29 \\
(.20)\end{array}$ & $\begin{array}{l}-.029 \\
(.023)\end{array}$ & $\begin{array}{r}-.034 \\
(.020)\end{array}$ & $\begin{array}{l}.089 \\
(.047)\end{array}$ & $\begin{array}{l}.017 \\
(.046)\end{array}$ \\
\hline $\begin{array}{l}\text { wage-weighted } \\
\text { occupation index }\end{array}$ & $\begin{array}{l}1.34 \\
(.24)\end{array}$ & $\begin{array}{l}.092 \\
(.068)\end{array}$ & $\begin{array}{l}.050 \\
(.057)\end{array}$ & $\begin{array}{r}-.091 \\
(.136)\end{array}$ & $\begin{array}{c}-.269^{*} \\
(.133)\end{array}$ \\
\hline $\begin{array}{l}\text { prop. change in } \\
\text { value added/worker }\end{array}$ & $\begin{array}{l}.72 \\
(.13)\end{array}$ & $\begin{array}{l}.080^{*} \\
(.035)\end{array}$ & $\begin{array}{c}.064^{*} \\
(.030)\end{array}$ & $\begin{array}{r}-.063 \\
(.071)\end{array}$ & $\begin{array}{r}-.056 \\
(.069)\end{array}$ \\
\hline $\begin{array}{l}\text { capital's share } \\
\text { of costs }\end{array}$ & $\begin{array}{l}.25 \\
(.05)\end{array}$ & $\begin{array}{l}-.217 \\
(.161)\end{array}$ & $\begin{array}{l}-.195 \\
(.136)\end{array}$ & $\begin{array}{l}.392 \\
(.321)\end{array}$ & $\begin{array}{l}.246 \\
(.314)\end{array}$ \\
\hline prop. female & $\begin{array}{l}.29 \\
(.32)\end{array}$ & $\begin{array}{l}.038 \\
(.021)\end{array}$ & $\begin{array}{c}.042^{*} \\
(.018)\end{array}$ & $\begin{array}{l}.020 \\
(.042)\end{array}$ & $\begin{array}{c}.099^{*} \\
(.041)\end{array}$ \\
\hline union & $\begin{array}{l}.47 \\
(.50)\end{array}$ & $\begin{array}{l}.004 \\
(.018)\end{array}$ & $\begin{array}{l}.003 \\
(.015)\end{array}$ & $\begin{array}{c}.303^{*} \\
(.036)\end{array}$ & $\begin{array}{c}.296^{*} \\
(.035)\end{array}$ \\
\hline union threat & $\begin{array}{l}.19 \\
(.24)\end{array}$ & $\begin{array}{c}-.001 \\
(.033)\end{array}$ & $\begin{array}{r}-.019 \\
(.028)\end{array}$ & $\begin{array}{c}-.146^{x} \\
(.065)\end{array}$ & $\begin{array}{l}-.007 \\
(.064)\end{array}$ \\
\hline $\begin{array}{l}\text { mean of } \\
\text { dependent variable }\end{array}$ & & .14 & .12 & .47 & .61 \\
\hline
\end{tabular}

$\mathrm{N}=3211$

All equations have dummy variables for 4-digit industry, region, and metropolitan location, not shown separately.

$|t| \geq 1.96$ 
Table 4

Method of Pay Equations

(Union and Nonunion Establishments)

\begin{tabular}{|c|c|c|c|c|c|c|}
\hline & \multicolumn{3}{|c|}{ Union Establishments $N=1523$} & \multicolumn{3}{|c|}{ Nonunion Establishments $N=1688$} \\
\hline & \multirow{2}{*}{$\begin{array}{c}\text { Mean } \\
\text { (Std Dev) }\end{array}$} & \multicolumn{2}{|c|}{ Dependent Variable } & \multirow{2}{*}{$\begin{array}{c}\text { Mean } \\
\text { (Std Dev) }\end{array}$} & \multicolumn{2}{|c|}{ Dependent Variable } \\
\hline & & $\begin{array}{l}\text { all } \\
\text { incentive }\end{array}$ & $\begin{array}{l}\text { single rates or } \\
\text { range:seniority }\end{array}$ & & $\begin{array}{c}\text { all } \\
\text { incentive }\end{array}$ & $\begin{array}{l}\text { single rates or } \\
\text { range:seniority }\end{array}$ \\
\hline $\ln ($ employment $)$ & $\begin{array}{c}4.90 \\
(1.13)\end{array}$ & $\begin{array}{l}.023^{*} \\
(.006)\end{array}$ & $\begin{array}{l}.007 \\
(.012)\end{array}$ & $\begin{array}{c}4.79 \\
(1.17)\end{array}$ & $\begin{array}{l}.020^{*} \\
(.006)\end{array}$ & $\begin{array}{c}.043^{*} \\
(.010)\end{array}$ \\
\hline $\begin{array}{l}\text { occupational } \\
\text { concentration }\end{array}$ & $\begin{array}{l}.26 \\
(.18)\end{array}$ & $\begin{array}{c}-.070 \\
(.036)\end{array}$ & $\begin{array}{c}-.003 \\
(.076)\end{array}$ & $\begin{array}{l}.32 \\
(.21)\end{array}$ & $\begin{array}{c}-.007 \\
(.031)\end{array}$ & $\begin{array}{l}.176^{*} \\
(.057)\end{array}$ \\
\hline $\begin{array}{l}\text { wage-weighted } \\
\text { occupation index }\end{array}$ & $\begin{array}{l}1.41 \\
(.25)\end{array}$ & $\begin{array}{l}.073 \\
(.103)\end{array}$ & $\begin{array}{l}.276 \\
(.217)\end{array}$ & $\begin{array}{l}1.27 \\
(.22)\end{array}$ & $\begin{array}{c}.099 \\
(.091)\end{array}$ & $\begin{array}{r}-.387^{*} \\
(.166)\end{array}$ \\
\hline $\begin{array}{l}\text { prop. change in } \\
\text { value added/worker }\end{array}$ & $\begin{array}{l}.73 \\
(.13)\end{array}$ & $\begin{array}{l}.080 \\
(.050)\end{array}$ & $\begin{array}{c}-.075 \\
(.105)\end{array}$ & $\begin{array}{l}.72 \\
(.13)\end{array}$ & $\begin{array}{c}.051 \\
(.053)\end{array}$ & $\begin{array}{c}.058 \\
(.096)\end{array}$ \\
\hline $\begin{array}{l}\text { capital's share } \\
\text { of costs }\end{array}$ & $\begin{array}{l}.26 \\
(.05)\end{array}$ & $\begin{array}{r}-.087 \\
(.211)\end{array}$ & $\begin{array}{l}.791 \\
(.444)\end{array}$ & $\begin{array}{l}.24 \\
(.05)\end{array}$ & $\begin{array}{l}-.199 \\
(.259)\end{array}$ & $\begin{array}{r}-.246 \\
(.473)\end{array}$ \\
\hline prop. female & $\begin{array}{l}.21 \\
(.29)\end{array}$ & $\begin{array}{l}.031 \\
(.032)\end{array}$ & $\begin{array}{l}.028 \\
(.067)\end{array}$ & $\begin{array}{l}.37 \\
(.33)\end{array}$ & $\begin{array}{l}.045 \\
(.027)\end{array}$ & $\begin{array}{l}.045 \\
(.050)\end{array}$ \\
\hline $\begin{array}{l}\text { mean of } \\
\text { dependent variable }\end{array}$ & & .11 & .66 & & .17 & .29 \\
\hline
\end{tabular}

All equations have dummy variables for 4-digit industry, region, and metropolitan location, not shown separately.

$|t| \geq 1.96$ 
Table 5

Method of Pay Equations

(Workers in Specified Occupations with DOT Matches)

\begin{tabular}{|c|c|c|c|}
\hline & \multirow{2}{*}{$\begin{array}{c}\text { Mean } \\
\text { (Std. Dev.) }\end{array}$} & \multicolumn{2}{|c|}{ Dependent Variable $=$ Worker Paid by } \\
\hline & & $\begin{array}{c}\text { all } \\
\text { incentives }\end{array}$ & $\begin{array}{l}\text { single rates or } \\
\text { range:seniority }\end{array}$ \\
\hline In(employment) & $\begin{array}{c}4.79 \\
(1.14)\end{array}$ & $\begin{array}{l}.025^{*} \\
(.007)\end{array}$ & $\begin{array}{l}.026^{*} \\
(.009)\end{array}$ \\
\hline $\begin{array}{l}\text { occupational } \\
\text { concentration }\end{array}$ & $\begin{array}{l}.29 \\
(.20)\end{array}$ & $\begin{array}{r}-.025 \\
(.038)\end{array}$ & $\begin{array}{l}.064 \\
(.054)\end{array}$ \\
\hline $\begin{array}{l}\text { wage-weighted } \\
\text { occupation index }\end{array}$ & $\begin{array}{l}1.35 \\
(.24)\end{array}$ & $\begin{array}{l}.137 \\
(.114)\end{array}$ & $\begin{array}{r}-.130 \\
(.164)\end{array}$ \\
\hline $\begin{array}{l}\text { prop. change in } \\
\text { value added/worker }\end{array}$ & $\begin{array}{l}.72 \\
(.12)\end{array}$ & $\begin{array}{l}.094 \\
(.058)\end{array}$ & $\begin{array}{r}-.008 \\
(.083)\end{array}$ \\
\hline $\begin{array}{l}\text { capital's share } \\
\text { of costs }\end{array}$ & $\begin{array}{l}.25 \\
(.04)\end{array}$ & $\begin{array}{r}-.269 \\
(.260)\end{array}$ & $\begin{array}{l}.449 \\
(.373)\end{array}$ \\
\hline prop. female & $\begin{array}{l}.29 \\
(.33)\end{array}$ & $\begin{array}{l}.001 \\
(.037)\end{array}$ & $\begin{array}{l}.072 \\
(.053)\end{array}$ \\
\hline union & $\begin{array}{l}.49 \\
(.50)\end{array}$ & $\begin{array}{r}-.012 \\
(.029)\end{array}$ & $\begin{array}{l}.364^{*} \\
(.041)\end{array}$ \\
\hline union threat & $\begin{array}{l}.19 \\
(.24)\end{array}$ & $\begin{array}{r}-.019 \\
(.052)\end{array}$ & $\begin{array}{r}-.055 \\
(.075)\end{array}$ \\
\hline
\end{tabular}




\begin{tabular}{|c|c|c|c|}
\hline & \multirow{2}{*}{$\begin{array}{c}\text { Mean } \\
\text { (Std. Dev.) }\end{array}$} & \multicolumn{2}{|c|}{ Dependent Variable $=$ Worker Paid by } \\
\hline & & $\begin{array}{c}\text { all } \\
\text { incentives }\end{array}$ & $\begin{array}{l}\text { single rates or } \\
\text { range:seniority }\end{array}$ \\
\hline $\begin{array}{l}\text { gen educ dev: } \\
\text { reasoning }\end{array}$ & $\begin{array}{l}2.69 \\
(.81)\end{array}$ & $\begin{array}{l}.050^{*} \\
(.020)\end{array}$ & $\begin{array}{r}-.032 \\
(.029)\end{array}$ \\
\hline $\begin{array}{l}\text { gen educ dev: } \\
\text { mathematics }\end{array}$ & $\begin{array}{c}1.92 \\
(1.07)\end{array}$ & $\begin{array}{l}.010 \\
(.014)\end{array}$ & $\begin{array}{r}-.023 \\
(.020)\end{array}$ \\
\hline $\begin{array}{l}\text { gen educ dev: } \\
\text { language }\end{array}$ & $\begin{array}{l}1.86 \\
(.80)\end{array}$ & $\begin{array}{c}-.051^{*} \\
(.014)\end{array}$ & $\begin{array}{l}.037 \\
(.021)\end{array}$ \\
\hline $\begin{array}{l}\text { specific voc } \\
\text { preparation }\end{array}$ & $\begin{array}{c}3.90 \\
(1.78)\end{array}$ & $\begin{array}{l}.005 \\
(.008)\end{array}$ & $\begin{array}{l}.016 \\
(.011)\end{array}$ \\
\hline $\begin{array}{l}\text { maximum } \\
\text { aptitude score }\end{array}$ & $\begin{array}{l}3.04 \\
(.52)\end{array}$ & $\begin{array}{r}-.005 \\
(.016)\end{array}$ & $\begin{array}{r}-.030 \\
(.023)\end{array}$ \\
\hline $\begin{array}{l}\text { diversified } \\
\text { duties }\end{array}$ & $\begin{array}{r}-.46 \\
(.40)\end{array}$ & $\begin{array}{c}-.046^{*} \\
(.017)\end{array}$ & $\begin{array}{l}.026 \\
(.024)\end{array}$ \\
\hline $\begin{array}{l}\text { precise } \\
\text { standards }\end{array}$ & $\begin{array}{l}.79 \\
(.40)\end{array}$ & $\begin{array}{l}.087^{*} \\
(.017)\end{array}$ & $\begin{array}{c}-.093^{*} \\
(.024)\end{array}$ \\
\hline $\begin{array}{l}\text { generalize } \\
\text { evaluate, decide }\end{array}$ & $\begin{array}{l}.51 \\
(.57)\end{array}$ & $\begin{array}{c}-.073^{*} \\
(.016)\end{array}$ & $\begin{array}{l}.061^{*} \\
(.024)\end{array}$ \\
\hline female & $\begin{array}{l}.29 \\
(.45)\end{array}$ & $\begin{array}{l}.070^{*} \\
(.019)\end{array}$ & $\begin{array}{r}-.030 \\
(.027)\end{array}$ \\
\hline $\begin{array}{l}\text { mean of } \\
\text { dependent variable }\end{array}$ & & .16 & .44 \\
\hline
\end{tabular}

$N=2888$

All equations have dummy variables for 4-digit industry, region, and metropolitan location, not shown separately.

$*|t| \geq 1.96$ 


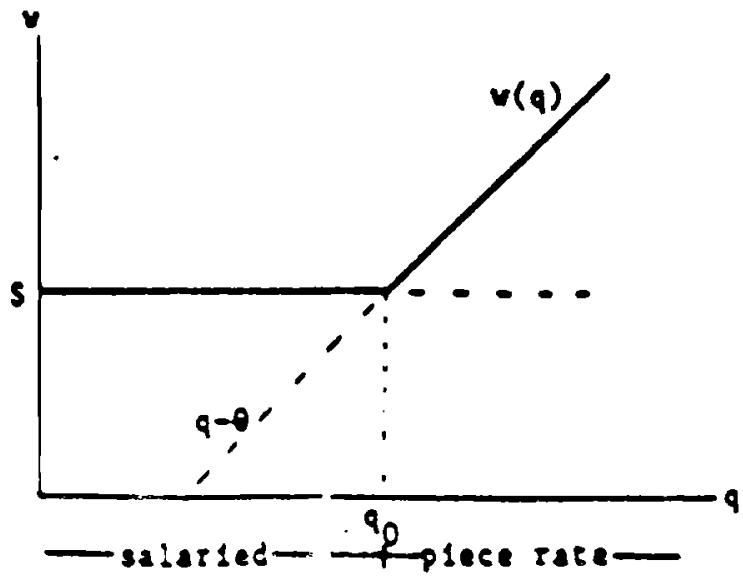

Figure 1

Salary and Piece Rate Firms

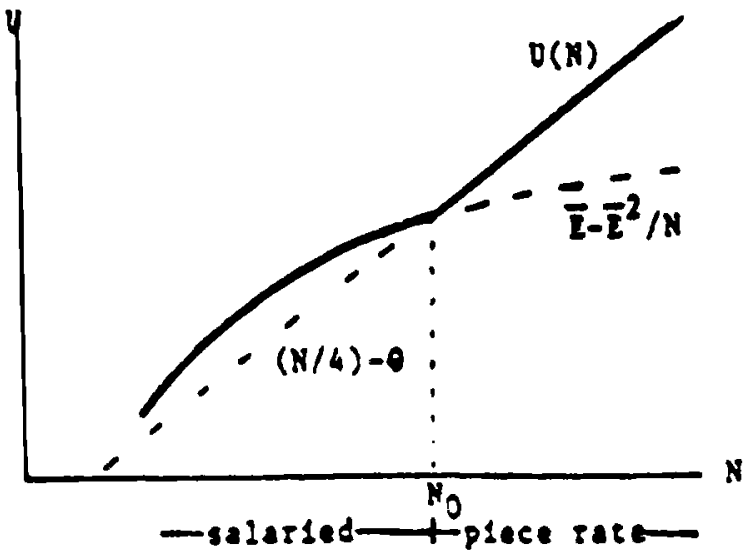

Figure 2

Salary and Fiece Rate Firms 


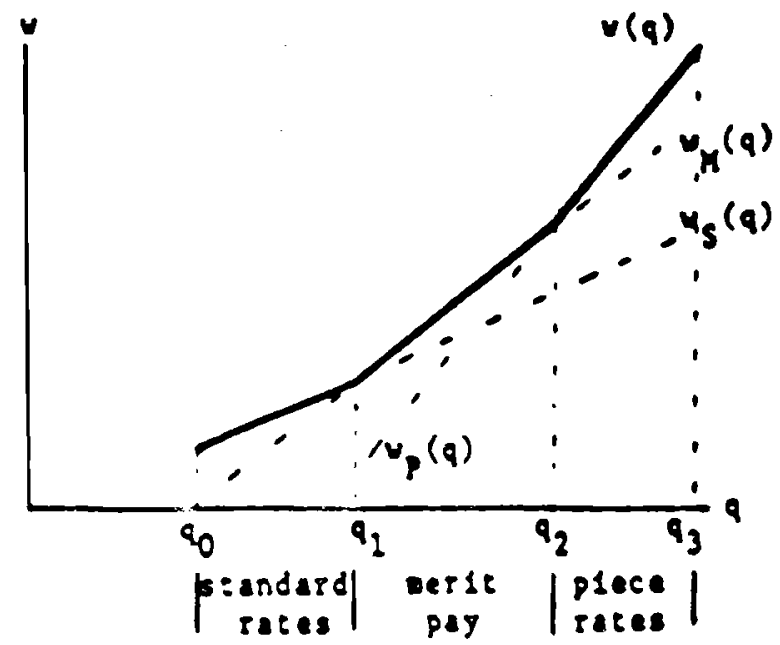

Figure 3

Standard Rate, Merit Pay, and Piece Rate Firms

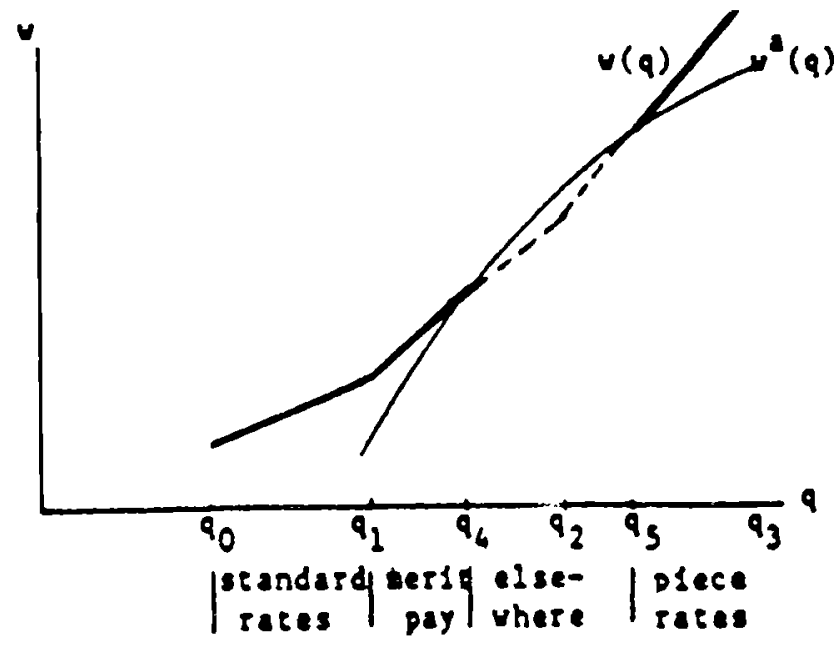

Figure 4

Standard Rate, Merit Pay, and Piece Rate Firms with Alternative-Wage Function 